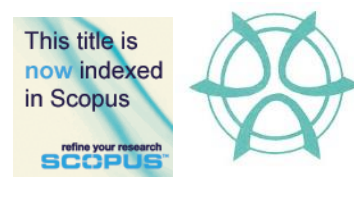

PLANNING MALAYSIA:

Journal of the Malaysian Institute of Planners

VOLUME 15 VOLUME 1 (2017), 347 - 356

\title{
HOUSING AFFORDABILITY IN THE STATE OF JOHOR
}

\author{
Mariana Mohamed Osman', Muhammad Adib Ramlee ${ }^{2}$, Nasriah Samsudin ${ }^{3}$, \\ Noor Suzilawati Rabe ${ }^{4}$, Muhammad Faris Abdullah ${ }^{5}$, \& Najihan Khalid ${ }^{6}$ \\ 1,2,3,4,5,6 Kulliyyah of Architecture \& Environmental Design \\ INTERNATIONAL ISLAMIC UNIVERSITY MALAYSIA
}

\begin{abstract}
The Malaysian property market has been facing significant changes in terms of housing price since a decade ago and these changes are different between states. The changes in housing prices are being supported by the economic theories of demand and supply as well as the regional economic and demographic factors such as income level, housing supply stock, speculative buying and population changes. This paper provides an overview of the affordable housing policy and elaborates on the housing affordability index for the districts in the State of Johor. Using datasets for year 2012 and 2014 in order to determine the median multiple of price-income ratio, this paper found that housing in all the districts were generally unaffordable. Some districts recorded HAI of severely unaffordable, while others in the seriously and moderately unaffordable index categories.
\end{abstract}

Keyword: Property market, housing affordability index, affordable housing, Johor, Malaysia

Date Received: $30^{\text {th }}$ April 2016

Date of Acceptance: $30^{\text {th }}$ October 2016 
Mariana Mohamed Osman, Muhammad Adib Ramlee, Nasriah, Noor Suzilawati, Muhammad Faris,, \& Najihan. Housing Affordability Index in the state of Johor

\section{INTRODUCTION}

Home ownership or the ability to own residential property has been a goal for many people in Malaysia. Owning a residential property provides sense of security which leads to happiness, productive and fulfilment of one's live. Moreover, home ownership will improve stability and the quality of life of the people. However, rapid economic growth of the nation has somewhat led to a surge in housing prices, making houses in Malaysia unaffordable to many of her citizens. Research by Hashim (2010), for instance, shows that price movement is influenced by the economic fundamentals, affecting purchasing power and borrowing capacity. Despite the various housing policies and strategies outlined and implemented to regulate and monitor the housing supply in Malaysia (Shuid, 2010), house prices in Malaysia keep increasing, especially in city areas. As a result, of late, housing prices and housing affordability have been a great concern to the Government of Malaysia.

The objective of this paper is to identify the affordable housing policies for the State of Johor and to analyse the housing affordability index at the district level in the state. It is hoped that the findings from this paper would contribute in making housing more affordable.

\section{LITERATURE REVIEW}

The idea of affordable housing recognizes the needs of households whose incomes are not sufficient to allow them to access appropriate housing in the market without assistance (Milligan et al., 2004). Thus, the term 'affordable housing' describes housing that assists lower income households in obtaining and paying for appropriate housing without experiencing undue financial hardship (Milligan et al., 2004).

The growth of economy and scarcity of land have caused major issues that resulted in many housing provision-related issues. As can be seen today the issues on housing affordability have been the main concerns to many agencies, political leaders, experts, public as well as governments in many countries. Although this issue is not new in Malaysia, but concrete solution has yet to be found. The problem is heightened in part because housing affordability carries different meaning to different parties. Therefore, a specific mechanism or a precise measure of housing affordability need to be considered to ensure aspired home owners can own their own houses as well as the basic need of shelter is not jeopardised.

Furthermore, housing also poses a significant impact on the competitiveness of local economy (Quigley \& Raphael, 2004). Review of literature indicated that if the house price is not competitive and beyond the affordability of the locals, companies in the area will find it difficult to keep and recruit personnel as fewer families could afford to own a house and reside in the area. Unaffordable housing will also contribute to financial problems, due to 
lower disposable income to finance the house mortgage (Hashim, 2010). Besides, due to tight housing market, people are unable to afford a house within or near to city centre as the prices offered are usually beyond affordability level of the people. As a consequence, households will have to reside farther from the city centre, where houses are relatively more affordable, and commute a longer distance to work in the city centre. This would result in higher transportation cost, longer journey time and exhaustion, which would reduce productivity at work place. Additionally, rising of house prices with stagnant income level will result in property overhang, where houses are left unsold.

As a rule of thumb, usually a house is considered affordable if it costs less than 30 percent of gross household income. However, this is not often the case in Malaysia. Even for houses marketed as "Rumah Mampu Milik (Affordable Houses)" by many developers in Malaysia, the price of these houses was set without referring to any established affordability fact or indexes as its basis (Hashim, 2010).

Thus, this paper aims to analyse the housing affordability index for the districts in the state of Johor so that it will become a basis or reference point in determining the price of housing which is sustainable to the population. According to a recent study by Khazanah Research Institute (KRI) Malaysia (2015), Johor has been ranked as the $9^{\text {th }}$ state in Malaysia in terms of housing affordability. The housing affordability index for Johor was 4.2 in 2014, which is considered as seriously unaffordable (KRI, 2015). The index was calculated based on the median all-house price over the median annual household income. This study will focus on the housing affordability index by districts level in the state of Johor for year 2012 and 2014.

\section{SITE PROFILE}

Johor is a state in Malaysia, located on the southern part of Peninsular Malaysia and is one of the most developed states in Malaysia. The state capital city of Johor is Johor Bahru and it is adjacent to the Republic of Singapore. The total acreage of Johor is $1,898.676$ hectares and it is the second-most populous state with the population of 3,230,440 people in 2010. The state is the 3rd largest conurbation in Malaysia and consist of 10 districts namely Kota TInggi, Ledang, Mersing, Segamat, Batu Pahat, Muar, Pontian, Kulai Jaya, Johor Bharu and Kluang. The districts are governed by 14 local authorities.

\section{JOHOR HOUSING POLICY}

The policy of Dasar Perumahan Rakyat Johor (DPRJ) or Housing Policy for Johorean were introduced in January 2014. The policies deal with several criteria related to the low cost and middle low cost types of housing. The policy proposed several types of housing components namely Perumahan Komuniti Johor A (PKJ A) or Johor Community Housing Type A, PKJ B, Rumah Mampu Milik Johor 
Mariana Mohamed Osman, Muhammad Adib Ramlee, Nasriah, Noor Suzilawati, Muhammad Faris,, \& Najihan. Housing Affordability Index in the state of Johor

(RMMJ) or Johor Affordable Homes and medium cost shop lot. The policy is applicable state-wide although there are some dissimilarity in housing requirements for Iskandar Malaysia as compared to the rest of the state.

\section{DPRJ Requirements for Areas within Iskandar Malaysia}

The percentage composition for low and medium cost housing within the Iskandar Malaysia is as shown in Table 1 below. Any new housing development within Iskandar Malaysia is required to provide several types of low and medium cost houses based on the categories stipulated in the DPRJ. Affordable housing should constitute a minimum of $40 \%$ of a housing development project. Out of this, 5\% should be the PKJ A, which are low cost units (high-rise flats/apartments) to be priced at RM42,000 and targeted for buyers with household income of less than RM3,000 per month. 10\% should be for PKJ B, to be priced at RM80,000 and targeted for those with income of less than RM4,500 per month. The RMMJ should constitute $20 \%$ and to be priced at RM150,000 and targeted for buyers with income of less than RM6,000 per month.

The requirement to provide these low and medium cost housing is to assist lower income earners to purchase houses at affordable prices. However, when compared with the household income survey for the year 2014, the average income of the people in the District of Johor Bahru, where Iskandar Malaysia is located in , is RM7,473 with a median of RM6,121 (Department of Statistic, 2015). This clearly show that $50 \%$ of the people in Iskandar Malaysia are within the medium income categories and eligible to buy these affordable houses.

Table 1 The Composition of Affordable Housing Based on DPRJ for Areas Within

\begin{tabular}{|c|c|c|c|c|c|c|}
\hline \multicolumn{7}{|c|}{ Iskandar Malaysia } \\
\hline House type & $\%$ & $\begin{array}{l}\text { Floor } \\
\text { Area } \\
\text { (Sq. ft.) }\end{array}$ & Plot Size & Type & $\begin{array}{l}\text { Maximum } \\
\text { Selling } \\
\text { Price } \\
(\mathrm{RM})\end{array}$ & $\begin{array}{l}\text { Target } \\
\text { Household } \\
\text { Income/month }\end{array}$ \\
\hline PKJ A & $5 \%$ & $720 \mathrm{sqft}$ & Nil & Strata & 42,000 & RM3,000 \\
\hline \multirow{2}{*}{ PKJ B } & \multirow{2}{*}{$10 \%$} & \multirow{2}{*}{$850 \mathrm{Sqft}$} & Nil & Strata & \multirow{2}{*}{80,000} & \multirow{2}{*}{ RM4,500 } \\
\hline & & & $16^{\prime} \times 55^{\prime}$ & Landed & & \\
\hline \multirow{3}{*}{ RMMJ } & \multirow{3}{*}{$20 \%$} & \multirow{3}{*}{1,000} & $18^{\prime} \times 60^{\prime}$ & Landed & \multirow{3}{*}{$* 150,000$} & \multirow{3}{*}{ RM6,000 } \\
\hline & & & $20^{\prime} \times 70$ & $\begin{array}{l}\text { Town } \\
\text { House }\end{array}$ & & \\
\hline & & & NA & Strata & & \\
\hline $\begin{array}{l}\text { Medium } \\
\text { Cost Shop }\end{array}$ & $5 \%$ & 1,200 & NA & Landed & 200,000 & RM7,000 \\
\hline Total & $40 \%$ & \multicolumn{5}{|c|}{ From Total Development Units } \\
\hline
\end{tabular}

Source: Pekeliling Am Kerajaan Johor on Dasar Perumahan Rakyat Johor, 2014 


\section{DPRJ Requirements for the Areas Outside of Iskandar Malaysia}

For areas outside Iskandar Malaysia, different affordable housing type composition and prices is applicable, as shown in Table 2 below. The main differences are in the percentage of PKJs and RMMJ, and the selling price of RMMJ and medium cost shop.

Table 2 The Composition of Affordable Housing Based on DPRJ for Areas Outside Iskandar Malaysia

\begin{tabular}{|c|c|c|c|c|c|c|}
\hline $\begin{array}{c}\text { House } \\
\text { Type }\end{array}$ & $\%$ & $\begin{array}{c}\text { Floor } \\
\text { Area } \\
\text { (Sq. ft.) }\end{array}$ & Plot Size & Type & $\begin{array}{c}\text { Maximum } \\
\text { Selling } \\
\text { Price } \\
\text { (RM) }\end{array}$ & $\begin{array}{c}\text { Target } \\
\text { Household } \\
\text { Income/ } \\
\text { Month }\end{array}$ \\
\hline PKJ A & $10 \%$ & 720 & $16^{\prime} \times 60$ & $\begin{array}{c}\text { Landed/ } \\
\text { Strata }\end{array}$ & 42,000 & RM3,000 \\
\hline PKJ B & $15 \%$ & 850 & $18^{\prime} \times 60$ & $\begin{array}{c}\text { Landed/ } \\
\text { Strata }\end{array}$ & 80,000 & RM4,500 \\
\hline RMMJ & $10 \%$ & 1,000 & $20^{\prime} \times 70$ & $\begin{array}{c}\text { Landed/ } \\
\text { Strata }\end{array}$ & $\begin{array}{c}* 140,000 \\
* 150,000\end{array}$ & RM6,000 \\
\hline $\begin{array}{c}\text { Medium } \\
\text { Cost Shop }\end{array}$ & $5 \%$ & 1,200 & NA & Landed & $\begin{array}{c}* 150,000 \\
* 170,000\end{array}$ & RM7,000 \\
\hline Total & $\mathbf{4 0 \%}$ & \multicolumn{7}{|l|}{ From Total Development Units } \\
\hline
\end{tabular}

* for city council area.

Source: Pekeliling Am Kerajaan Johor on Dasar Perumahan Rakyat Johor, 2014

\section{HOUSING AFFORDABILITY INDEX}

Affordable housing is related to the ability of a household to pay for their house (EsruqLabin, 2014). The concept of housing affordability can be measured from three perspectives, namely Repayment Affordability, Purchase Affordability and Price Income Ratio (PIR). For the calculation of housing affordability index (HAI) for each districts in Johor, the PIR was used. To derive the HAIs, the median multiple formula, which makes use of the annual income and median of all house prices, was employed (Figure 1). Data on population income and house price for year 2012 and 2014 were sourced from the Department of Statistics Malaysia and the National Property Information Centre of the Valuation and Property Services Department Malaysia.

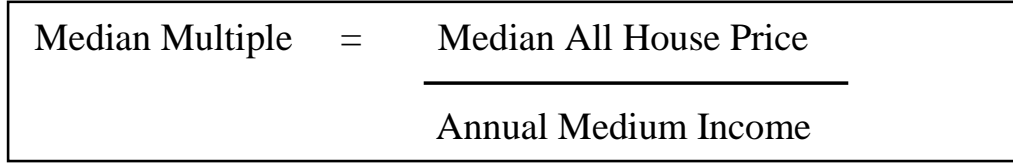

Figure 1 Median Multiple Formula Source: Khazanah Research Institute, 2015

The resulting median multiple scores were then compared to the housing affordability index categories as shown in Table 3 below. 
Mariana Mohamed Osman, Muhammad Adib Ramlee, Nasriah, Noor Suzilawati, Muhammad Faris,, \& Najihan. Housing Affordability Index in the state of Johor

Table 3 Housing Affordability Rating Categories

\begin{tabular}{lc}
\hline \multicolumn{1}{c}{ Category } & Median Multiple \\
\hline Severely Unaffordable & 5.1 and Over \\
Seriously Unaffordable & $4.1-5.0$ \\
Moderately Unaffordable & $3.1-4.0$ \\
Affordable & 3.0 and Under \\
\hline Source: Demographia, 2016.
\end{tabular}

\section{FINDINGS}

Table 4 below shows the median multiple and the associated HAIs calculated for each district in Johor for year 2012 and 2014. Generally, there has been an improvement in terms of housing affordability in many of the districts from 2012 to 2014. Out of the ten districts in Johor, eight have experience improved housing affordability in 2014 as compared to 2012. For instance, the District of Kota Tinggi recorded a median multiple of 4.7 in 2014, as compared to 6.9 in 2012. This could be due to increase in median income among the population higher than the increase of median house price in the district. Other districts that experienced improved housing affordability were Ledang, Batu Pahat, Muar, Pontian, Kulai Jaya, Johor Bahru and Kluang. Despite the improvement in affordability, the median multiple for these districts were still above 3.0, indicating housing unaffordability. For example, for the District of Ledang, the median multiple for 2014 was 5.3, indicating that housing in the district was severely unaffordable despite slight improvement in the affordability index from 2012.

Two districts experienced worsening median multiple, which were Mersing and Segamat. The median multiple for Mersing was 5.7 in 2012 but worsen in 2014 to 6.1. For Segamat, it worsen slightly from 5.2 in 2012 to 5.3 in 2014. For these districts, the HAI indicated that housing in the districts were severely unaffordable both in 2012 and in 2014. 
PLANNING MALAYSIA:

Journal of the Malaysia Institute of Planners (2017)

Table 4 HAI for 2012 and 2014 by Districts in Johor

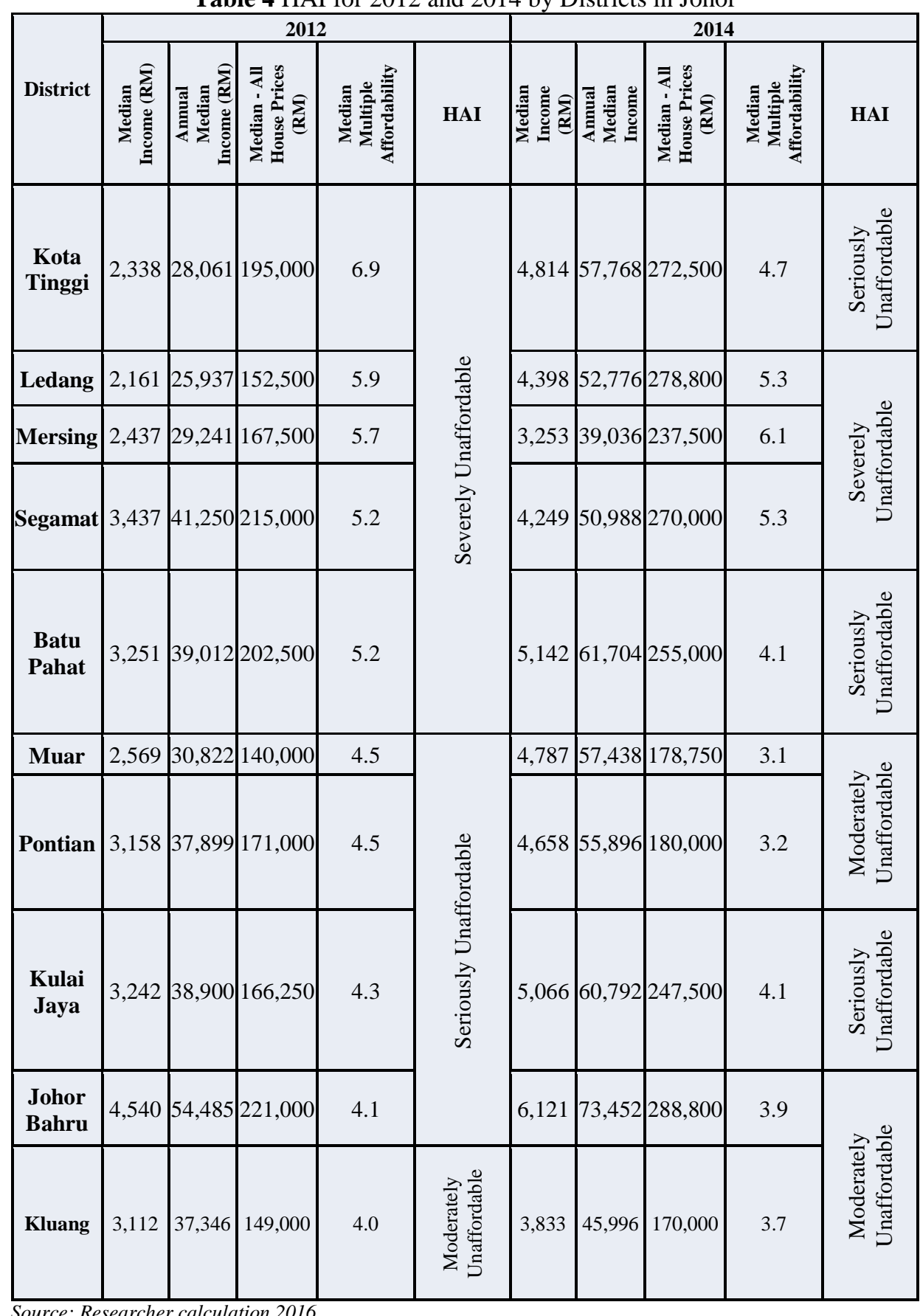


Mariana Mohamed Osman, Muhammad Adib Ramlee, Nasriah, Noor Suzilawati, Muhammad Faris,, \& Najihan. Housing Affordability Index in the state of Johor

Affordable house price for each district was then derived based on the annual median income of population of each district multiplied affordability index of 3.0. The results are as shown in Table 5. These are the maximum median house price if houses in the districts were to be made affordable to the population of the districts.

Table 5 Affordable House Prices by District in Johor based on Data for 2014

\begin{tabular}{|l|c|c|c|}
\hline \multicolumn{1}{|c|}{ District } & $\begin{array}{c}\text { Annual Median } \\
\text { Income (RM) }\end{array}$ & $\begin{array}{c}\text { Median All House } \\
\text { Price (RM) }\end{array}$ & $\begin{array}{c}\text { Affordable } \\
\text { Maximum Median } \\
\text { House Price Based } \\
\text { on Housing } \\
\text { Affordability Index } \\
\text { Ratio of 3.0 }\end{array}$ \\
\hline Mersing & 39,036 & 237,500 & 117,108 \\
\hline Segamat & 50,988 & 270,000 & 152,964 \\
\hline Ledang & 52,776 & 278,800 & 158,328 \\
\hline Kota Tinggi & 57,768 & 272,500 & 173,304 \\
\hline Batu Pahat & 61,704 & 255,000 & 185,112 \\
\hline Kulai jaya & 60,792 & 247,500 & 182,376 \\
\hline Johor bahru & 73,452 & 288,800 & 220,356 \\
\hline kluang & 45,996 & 170,000 & 137,988 \\
\hline Pontian & 55,896 & 180,000 & 167,688 \\
\hline Muar & 57,438 & 178,750 & 172,314 \\
\hline
\end{tabular}

Source: Researcher calculation, 2016

Affordable House Prices in Johor by Districts

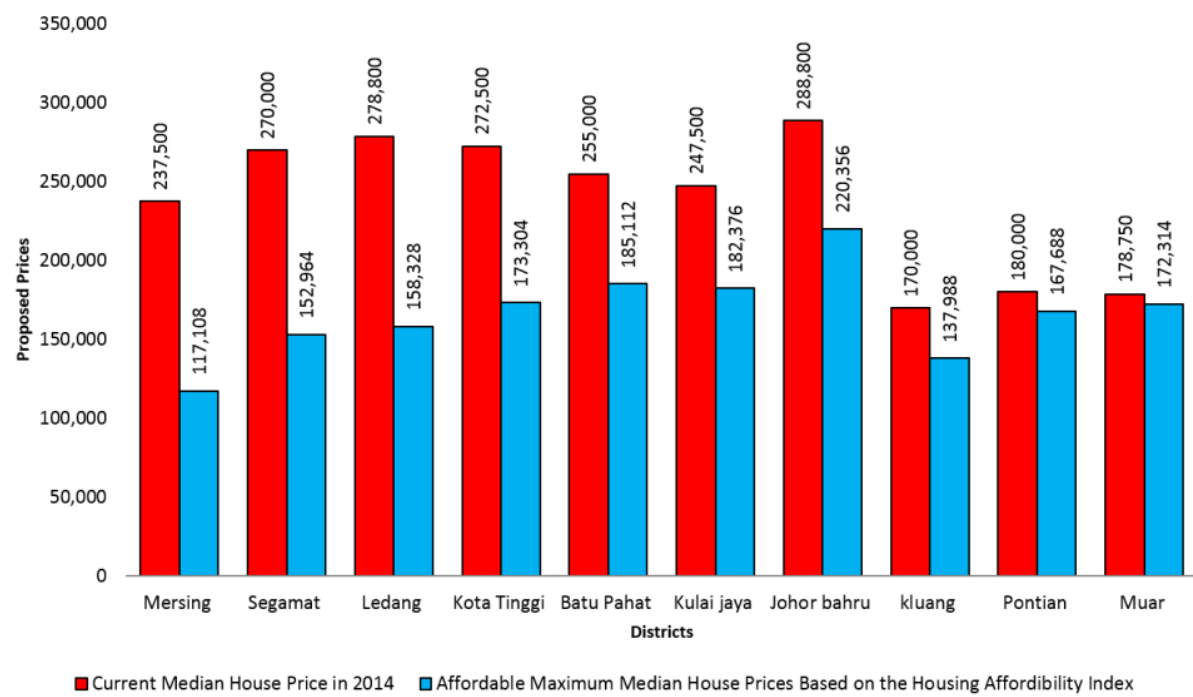

Figure 2 Affordable House Price in Johor by Districts in 2012 and 2014 Source: Researcher calculation, 2016 
PLANNING MALAYSIA:

Journal of the Malaysia Institute of Planners (2017)

Figure 2 compares the actual median house price in 2014 and the derived affordable maximum median house price based on population median income. In all of the districts, the actual median house price is higher than the derived affordable median house price, indicating that housing in the districts are unaffordable given the income of the population. The difference between actual median house price and the derived affordable median house price are largest in the districts of Mersing, Segamat and Ledang. This corroborates the HAIs in Table 5 where the three districts were identified with severely unaffordable housing. Smaller difference between actual median house price and the derived affordable median house price occurs in the districts of Kluang, Pontian and Muar, all of which were identified with moderately unaffordable HAI in Table 5.

\section{CONCLUSION}

In conclusion, this paper has shown that despite the presence of affordable housing policy for the State of Johor, house prices in the state is largely higher than what the population can afford, making housing unaffordable to the population. The housing affordability index for some of the districts was worst at severely unaffordable while others were in the seriously and moderately unaffordable categories. None of the districts was found to have median house price that commensurate the population income. Although some districts experienced improvement in terms of housing affordability in 2014, the HAI of these district was still in the unaffordable rating categories.

\section{REFERENCES}

Cagamas Holdings Berhad (2010). Housing the nation: policies, issues and prospects. Kuala Lumpur: Cagamas Holdings Berhad.

Chander, R. (1977). Housing needs versus effective demand in Malaysia. Kuala Lumpur: Department of Statistics Malaysia.

Demographia (2016). 12 $2^{\text {th }}$ annual Demographia international housing survey.

Department of Housing, Johor State Government (2014). Pekeliling Am Kerajaan Johor. Retrieved 17/01/2017 from http://erumah.johor.gov.my/ePerumahan/ home/index.htm.

Department of Statistics Malaysia (2007). Population and housing census, Malaysia 2007. Putrajaya: Department of Statistics, Malaysia.

Esruq-Labin, A. M. J., Che Ani, A. I., Mohd Tawil, N., Nawi, M. N. M., \& Othuman Mydin, M. A. (2014). Criteria for affordable housing performance measurement: a review. In Proceedings of the Emerging Technology for Sustainable Development Congress, August 5, Bangi, Malaysia.

Hadi, A. N. (2015). Housing policy and housing program in Malaysia. Retrieved from http://www.academia.edu/12498641/Housing_Policy_and_Housing_Program_ In_Malaysia.

Hashim, Z.A. (2010) House price and affordability in housing in Malaysia. Akademika, 78, 37-46. 
Mariana Mohamed Osman, Muhammad Adib Ramlee, Nasriah, Noor Suzilawati, Muhammad Faris,, \& Najihan. Housing Affordability Index in the state of Johor

Khazanah Research Institute [KRI] (2015). Making housing affordable. Kuala Lumpur: Khazanah Research Institute.

Khazanah Research Institute [KRI] (2016). The state of household. Kuala Lumpur: Khazanah Research Institute.

Milligan, V., Gurran, N., Lawson, J., Phibbs, P., \& Phillips, R. (2009). Innovation in affordable housing in Australia: bringing policy and practice for not-for-profit housing organisations together, AHURI Final Report No. 134. Melbourne: Australian Housing and Urban Research Institute Limited.

National Property Information Centre (2012). Data on housing property for demand and supply 2012. Retrieved from http://napic.jpph.gov.my/portal/publication.

National Property Information Centre (2014). Data on housing property for demand and supply 2014. Retrieved from http://napic.jpph.gov.my/portal/publication.

Qigley, J., \& Raphael, S. (2004). Is housing affordable? Journal of Economic Perspectives, 18(1), 191-214.

Shuid, S. (2010) Policies and strategies for housing supply in Malaysia. Kuala Lumpur: Ministry of Urban Wellbeing Housing and Local Government, Malaysia.

Sliogeris, E., Crabtree, L., Phibs, P., \& Johnston, K. (2008). Housing affordability literature review and affordable housing program audit. Penrith, N.S.W: University of Western Sydney. Retrieved from http://www.uws.edu.au/_data/assets/pdf_file/0004/164623/landcom_report_2 008-07-21.pdf

Wendell, C., \& Pavletich, H. (1988). 8th annual Demographia international housing affordability survey. Retrieved from http://www.demographia.com/dhi.pdf

Zainun, N. Y., \& Eftekhari, M. (2010). Forecasting low-cost housing demand in Johor Bahru, Malaysia using artificial neural networks2 (ANN). Journal of Mathematics Research, 2(1), 14-15. 